"Impact of corporate governance mechanisms on financial reporting quality: a study of Indian GAAP and Indian Accounting Standards"

\begin{tabular}{|c|c|}
\hline \multirow{5}{*}{ AUTHORS } & Faozi A. Almaqtari iD https://orcid.org/0000-0002-5625-3643 \\
\hline & R http://www.researcherid.com/rid/V-7135-2018 \\
\hline & Abdulwahid Abdullah Hashed (D https://orcid.org/0000-0002-6791-235X \\
\hline & Mohd Shamim iD https://orcid.org/0000-0002-0529-5851 \\
\hline & Waleed M. Al-ahdal \\
\hline ARTICLE INFO & $\begin{array}{l}\text { Faozi A. Almaqtari, Abdulwahid Abdullah Hashed, Mohd Shamim and Waleed } \\
\text { M. Al-ahdal (2020). Impact of corporate governance mechanisms on financial } \\
\text { reporting quality: a study of Indian GAAP and Indian Accounting Standards. } \\
\text { Problems and Perspectives in Management, 18(4), 1-13. } \\
\text { doi:10.21511/ppm.18(4).2020.01 }\end{array}$ \\
\hline DOI & http://dx.doi.org/10.21511/ppm.18(4).2020.01 \\
\hline RELEASED ON & Tuesday, 13 October 2020 \\
\hline RECEIVED ON & Thursday, 09 July 2020 \\
\hline ACCEPTED ON & Thursday, 01 October 2020 \\
\hline & $(\mathrm{cc}) \mathrm{EY}$ \\
\hline LICENSE & $\begin{array}{l}\text { This work is licensed under a Creative Commons Attribution } 4.0 \text { International } \\
\text { License }\end{array}$ \\
\hline JOURNAL & "Problems and Perspectives in Management" \\
\hline ISSN PRINT & $1727-7051$ \\
\hline ISSN ONLINE & $1810-5467$ \\
\hline PUBLISHER & LLC “Consulting Publishing Company "Business Perspectives" \\
\hline FOUNDER & LLC "Consulting Publishing Company "Business Perspectives" \\
\hline & $\begin{array}{l}= \pm: \\
= \pm:-\end{array}$ \\
\hline NUMBER OF REFERENCES & NUMBER OF FIGURES \\
\hline 53 & 4 \\
\hline
\end{tabular}

(c) The author(s) 2023. This publication is an open access article. 


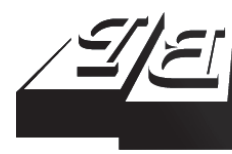

BUSINESS PERSPECTIVES

○

LLC "CPC "Business Perspectives" Hryhorii Skovoroda lane, 10, Sumy, 40022, Ukraine www.businessperspectives.org
Received on: $9^{\text {th }}$ of July, 2020 Accepted on: $1^{\text {st }}$ of October, 2020 Published on: $13^{\text {th }}$ of October, 2020

(C) Faozi A. Almaqtari, Abdulwahid Abdullah Hashed, Mohd Shamim, Waleed M. Al-ahdal, 2020

Faozi A. Almaqtari, Ph.D., Assistant Professor, Department of Accounting, College of Commerce and Economics, Hodeidah University, Yemen.

Abdulwahid Abdullah Hashed, Ph.D. Assistant Professor, Department of Accounting, College of Business Administration, Prince Sattam Bin Abdulaziz University, Saudi Arabia: Department of Accounting, College of Commerce and Economics, Hodeidah University, Yemen. (Corresponding author)

Mohd Shamim, Ph.D., Professor, Department of Commerce, Aligarh Muslim University, Aligarh, India.

Waleed M. Al-ahdal, Research Scholar, Faculty of Commerce, Banaras Hindu University, Banaras, India.
This is an Open Access article, distributed under the terms of the Creative Commons Attribution 4.0 International license, which permits unrestricted re-use, distribution, and reproduction in any medium, provided the original work is properly cited.

Conflict of interest statement: Author(s) reported no conflict of interest
Faozi A. Almaqtari (Yemen), Abdulwahid Abdullah Hashed (Saudi Arabia), Mohd Shamim (India), Waleed M. Al-ahdal (India)

\section{IMPACT OF CORPORATE GOVERNANCE MECHANISMS ON FINANCIAL REPORTING QUALITY: A STUDY OF INDIAN GAAP AND INDIAN ACCOUNTING STANDARDS}

\begin{abstract}
The present study examines the impact of corporate governance mechanisms on financial reporting quality under Indian GAAP and Indian Accounting Standards (Ind. AS). A sample of 97 companies listed on the Bombay Stock Exchange is selected. Corporate governance mechanisms have been considered as independent variables, and financial reporting quality is the dependent variable. Corporate governance is measured by board effectiveness (board size, independence, diligence, and expertise), audit committee attributes (size, independence, diligence, and expertise), foreign ownership, and audit quality. Descriptive statistics, correlation, and OLS regression are conducted to estimate the results. The study results reveal that board characteristics and audit committee attributes, except for audit committee diligence, have a significant effect on financial reporting quality. However, the impact of board diligence and audit committee attributes is negative. Foreign ownership has no contribution to financial reporting quality, but audit quality has a significant effect. The findings of the study have considerable implications for regulators, policymakers, managers, investors, analysts, and academicians. More emphasis should be given to compliance with Ind. AS, and an oversight body for compliance with Ind. AS should be established.
\end{abstract}

Keywords

corporate governance, GAAP, Ind. AS, financial reporting, board effectiveness, audit committee effectiveness, foreign ownership, audit quality, India

JEL Classification M10, M40, M41

\section{INTRODUCTION}

India represents a distinctive environment to tackle corporate governance (CG) issues and comply with the latest converged IFRS requirements. It represents an interesting and important context to assess the influence of CG on IFRS converged standards, Ind. AS (Almaqtari, Al-Hattami et al., 2020). To ensure a smooth transition to IFRS in India from $1^{\text {st }}$ April 2016, the Institute of Chartered Accountants of India (ICAI) announced a road map for the adoption of Indian Accounting Standards (Ind. AS) (Deloitte, 2017). The convergence of the Indian GAAP to Ind. AS is considered as an extraordinary and essential event in India. This convergence aims to align the local GAAP (Indian GAAP) with international standards (IFRS) and enhance financial reporting quality (FRQ) (Almaqtari, Farhan, et al., 2020). On $16^{\text {th }}$ February 2015, the Ministry of Corporate Affairs (MCA) notified the adoption of Ind. AS in the Gazette effective from $1^{\text {st }}$ April 2015. Accordingly, 35 Indian GAAP standards are notified by the MCA as Ind. AS (KPMG, 2015). Ind. AS are named and numbered in the same 
manner as IFRS standards. A road map was released by the MCA to require companies that have a net worth of Rs. 500 crore or more to prepare their financial statements based on Ind. AS from $1^{\text {st }}$ April 2016. Further, another class of companies listed or in the process of listing with a net worth of less than Rs. 500 or Rs. 250 crore or more will have to mandatorily implement Ind. AS from 1st $^{\text {Ap }}$ Apil 2017 (Deloitte, 2017). Recent studies (e.g., Almaqtari, Farhan, et al., 2020; Almaqtari, Shamim, et al., 2020) state that there is a dearth of studies that examine the impact of corporate governance on accounting standards issues, especially after IFRS convergence in India. Accordingly, the present study investigates the influence of CG on FRQ pre- and post-convergence to Ind. AS.

\section{LITERATURE REVIEW}

\subsection{Board effectiveness}

Prior studies have documented evidence of the effect of board size on FRQ. For example, Onuorah et al. (2016) state that a small board size will promote the level of cohesion and coordination among them and managers, which is expected to enhance FRQ. Similarly, Ditropoulos and Asteriou (2010) report a relationship between FRQ and CG attributes, including board size. Contradictory, some other studies report no correlation between board size and FRQ (Xie et al., 2003; Chalaki et al., 2012; Ahmed \& Duellman, 2006). Concerning board independence, Ahmed and Duellman (2006) advocate a definite relationship between CG characteristics, including board independence, and FRQ. Further,Koh et al. (2007) argue that a higher portion of independent members of the board contributes to enhancing FRQ. However, Onuorah et al. (2016) state that board independence is negatively associated with FRQ. Petra (2007) found that independent board members are not sufficiently qualified to control the managers. Further, independent members' presence makes no effort to guarantee FRQ (Ahmed et al. 2006). Concerning board meetings, Sarkar et al. (2008) report that board meetings' higher attendance contributes to information quality. Similarly, Chou et al. (2010) found that higher board diligence represented by regular attendance of board meetings is an essential vehicle for the supervising role. In the same line, Xie et al. (2003) and Sarkar et al. (2008) report an association between meeting frequency of boards and lower levels of earnings management. This is also similar to Cho and Rui (2009) and Firth et al. (2007), who stated that earnings responsive coefficient increases with a high meeting frequen- cy level. As far as board expertise is concerned, the evidence of the effect of board expertise on FRQ is established by different studies. Xie et al. (2003) find that earnings management is unlikely to happen in firms that maintain a higher portion of independent and finally literate members. Consistently, García-Meca and Garcia-Sanchez (2018) confirmed that management expertise plays a vital role in FRQ and that capable managers are less possibly to commit opportunistic earnings management to meet bank short-term earnings benchmarks. Similarly, Onuorah et al. (2016) reported that board experience positively affects FRQ proxied by the discretionary accruals. Further, Krishnan and Visvanathan (2008) indicate that board financial expertise enhances board members' efficiency in carrying their monitoring role and accordingly enhances the level of FRQ.

\subsection{Audit committee effectiveness}

Felo et al. (2003) report that the large size of AC positively influences FRQ. In the same context, Bedard et al. (2004) conclude that the likelihood of aggressive earnings management has no significant relationship with AC size. In the same line, Yang and Krishnan (2005) indicate that a larger AC is less possibly to manipulate earnings. Likewise, Choi et al. (2004) indicate that a large size of $\mathrm{AC}$ is more likely to comprise different qualified and varied expertise members, which could be an efficient driver to enhance FRQ. Contradictory to the evidence mentioned above, Davidson et al. (2005) concluded insignificant evidence of the positive association between FRQ and AC size. Concerning AC independence, Bedard et al. (2004) and Abbott et al. (2000) report a significant relationship between low levels of earnings management and fraudulent financial reporting, on the one hand, and a higher propor- 
tion of independent members in AC. However, Yang and Krishnan (2005) and Rahman and Ali (2006) demonstrate the insignificant association between the level of earnings management and the existence of independent members in the AC. In the same context, Beasley et al. (1996) and Abbott et al. (2004) agree that financial statement fraud or earning restatements is linked with the independence of the AC. Regarding AC meetings, Bedard et al. (2004) conclude that there is no significant association between AC meetings' frequency with the likelihood of aggressive earnings management. Consistently, Xie et al. (2003) report a significant association between the AC's activities and the quality of earnings. Further, Van der Zahn and Tower (2004) indicate that earnings management is less likely to occur with the existence of more efficient AC. Likewise, Beasley et al. (1996) indicated that fraud companies in specific industries had fewer AC meetings. In the context of $\mathrm{AC}$ expertise, numerous literature is in favor of a higher number of AC expert members for better FRQ. Beasley et al. (2009) and Chen et al. (2006) found that expertise in the face of increasingly complex information assures FRQ. In the same vein, Cohen et al. (2013) advocate that AC expertise positively influences FRQ. Alike, Cohen et al. (2013) stated that investors should appoint an accounting and financial expert director on the AC for positive FRQ and AC effectiveness. In the same way, Cohen et al. (2013) argued that industry experts' attendance on AC enhances FRQ. Further, Carcello and Neal (2003) state that apart from AC members' independence, their financial expertise is another determinant of FRQ.

\subsection{Foreign ownership}

Lee et al. (2013) reveal that listed firms in China have a greater percentage of foreign ownership, expected to enhance their FRQ more under IFRS-converged CAS. Similarly, subsequent research indicates a positive correlation between the increase in foreign ownership, governance transparency, and earning a responsive coefficient (Dong \& Xue, 2010). Some other studies suggest that foreign ownership is related to greater corporate accountability and less to information asymmetry (Aggarwal et al., 2011). In contrast, Chalaki et al. (2012) indicated no relationship between CG attributes, including ownership concentration, institutional ownership, and FRQ.

\subsection{Audit quality}

Onuorah et al. (2016) revealed that external audit quality has a positive effect on the FRQ proxied by the discretionary accruals of a firm. Further, Davidson et al. (2005) state that there is no relationship between the presence of Big 5 auditor and earnings management. It was also found that the external audit plays a vital role in monitoring management and enhancing FRQ (Watts \& Zimmerman, 1983). In the same vein, financial information is more reliable for Big 4 firms than other companies (Becker et al., 1998).

\section{AIM OF THE STUDY}

The present study investigates the impact of corporate governance mechanisms on financial reporting quality under Indian GAAP and Ind. AS.

\subsection{Hypotheses of the study}

Based on the arguments presented in the literature review and the aim of the study, the hypotheses of the study are as follows:

$H_{0} 1$ : There is no significant difference in the impact of board size on financial reporting quality between Ind. AS and Indian GAAP.

$\mathrm{H}_{0}$ 2: There is no significant difference in the impact of board independence on financial reporting quality between Ind. AS and Indian GAAP.

$\mathrm{H}_{0}$ 3: There is no significant difference in the impact of board diligence on financial reporting quality between Ind. AS and Indian GAAP.

$\mathrm{H}_{0} 4$ : There is no significant difference in the impact of board expertise on financial reporting quality between Ind. AS and Indian GAAP.

$H_{0}$ 5: There is no significant difference in the impact of AC size on financial reporting quality between Ind. AS and Indian GAAP.

$H_{0} 6$ : There is no significant difference in the impact of AC independence on financial reporting quality between Ind. AS and Indian 
GAAP.

$H_{0} 7$ : There is no significant difference in the impact of AC diligence on financial reporting quality between Ind. AS and Indian GAAP.

$H_{0} 8$ : There is no significant difference in the impact of AC expertise on financial reporting quality between Ind. AS and Indian GAAP.

$H_{0} 9$ : There is no significant difference in the impact of foreign ownership on financial reporting quality between Ind. AS and Indian GAAP.

$H_{0} 10$ : There is no significant difference in the impact of audit quality on financial reporting quality between Ind. AS and Indian GAAP.

\section{METHOD}

\subsection{Sample selection}

The sample for the present study includes 97 listed firms listed in the BSE based on using Ind. AS, availability of data, and higher capitalization. The study covers the period from 2014 to 2018 as it is the most recent years in which companies started shifting to Ind. AS. The data required for CG,
Ind. AS, and firm-specific variables are manually collected from firms' published annual reports using content analysis. Data for firms' specific and some other financial variables were also extracted from audited firms' financial statements, which are available in the stock market database or the websites of the respected companies.

\subsection{Operational definitions of variables}

\subsubsection{Independent variables of corporate governance mechanisms}

The present study covers four categories of independent variables: board of directors' effectiveness, AC effectiveness, foreign ownership, and audit quality as a measurement of CG mechanism. Appendix A illustrates the variables, definitions, and measurements.

\subsubsection{Dependent variable}

Following Chalaki et al. (2012), the present study measures FRQ using the McNichols (2002) model. McNichols (2002) considered that the standard deviation of the residuals or the error terms could indicate and measure financial reporting quality. The higher output of the estimated residuals signifies greater discretionary accruals and so a low

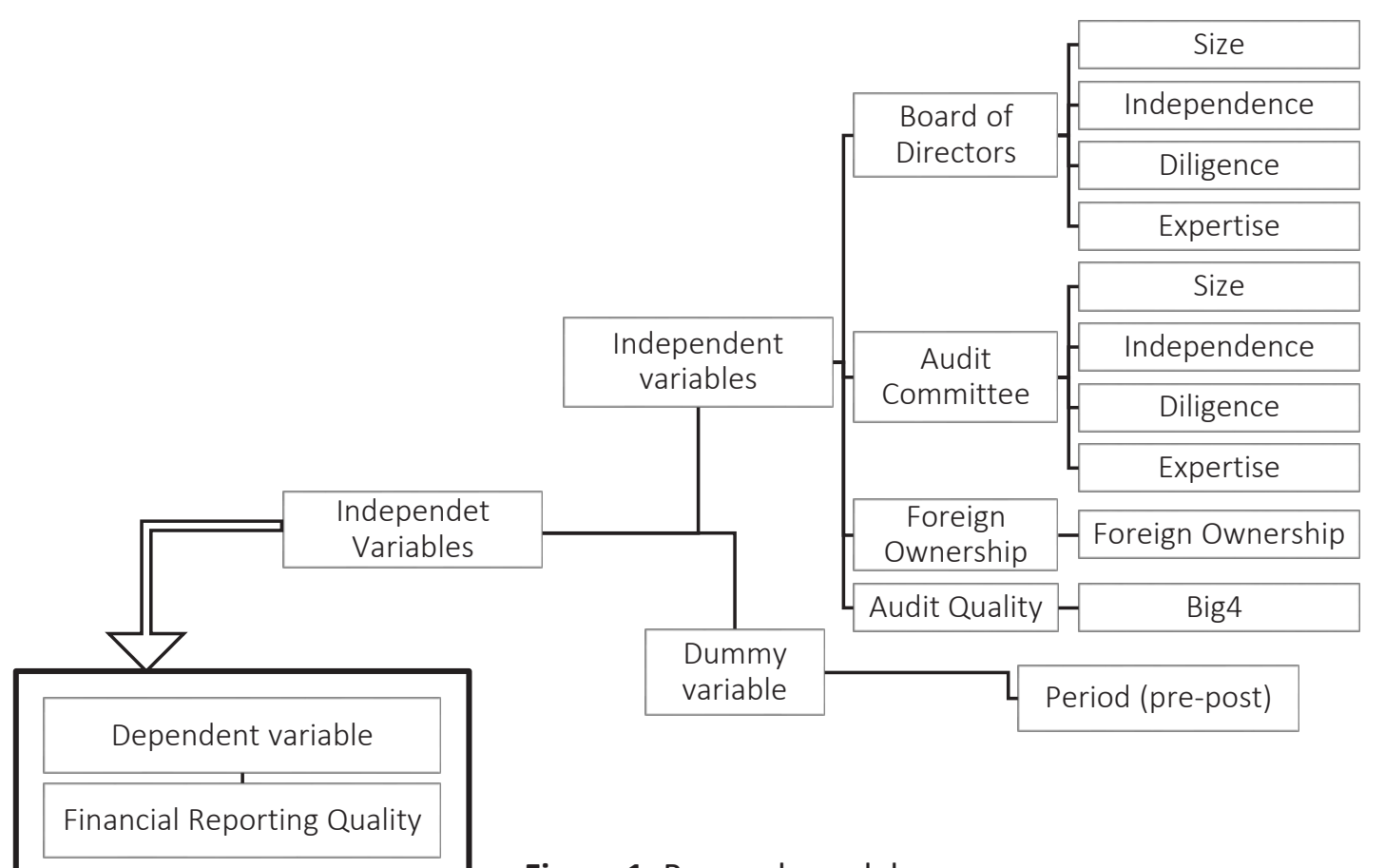

Figure 1. Research model 
financial information quality. Following is the equation:

$$
\begin{aligned}
& \frac{T C A_{j, t}}{A S_{j, t}}=\beta_{0 j}+\beta_{1, j} \frac{C F O_{j, t-1}}{A S_{j, t}}+ \\
& +\beta_{2 j} \frac{C F O_{j, t}}{A S_{j, t}}+\beta_{3 j} \frac{C F O_{j, t+1}}{A S_{j, t}}+ \\
& +\beta_{4 j} \frac{R E V_{j, t}}{A S_{j, t}}+\beta_{5 j} \frac{P P E_{j, t}}{A S_{j, t}}+\varepsilon_{j, t}
\end{aligned}
$$

where $T C A_{j, t}$ of a firm $j$ is aggregate current accruals in year $t, \mathrm{CFO}_{j, t}$ is the operating cash flows (OCF) of the current period, $\mathrm{CFO}_{i, t-1}$ is the OCF of the prior period, $C F O_{i, t+1}$ is the OCF of the coming period, $\triangle \mathrm{REV}$ is the change in revenues, and $P P E_{j, t}$ is the level of property, plant, and equipment. All the variables in the equation are scaled by lagged by assets. The variables of the study measure the impact of CG on FRQ under Ind. AS (see Figure 1).

\subsection{Model specification}

Following is the research model that examines the impact of CG mechanisms on FRQ:

$$
\begin{aligned}
& F R Q_{i t}=\beta_{0}+\beta_{1} \text { BSIZE }_{i t}+ \\
& +\beta_{2} \text { BIND }_{i t}+\beta_{3} \text { BDEL }_{i t}+ \\
& +\beta_{4} B E X P_{i t}+\beta_{5} \text { ACSIZE }_{i t}+ \\
& +\beta_{6} \text { ACIND }_{i t}+\beta_{7} \text { DEL }_{i t}+ \\
& +\beta_{8} A_{C E X P_{i t}+\beta_{9} \text { FOWN }_{i t}+}+ \\
& +\beta_{10}{\text { Big }- \text { Four }_{i t}+}_{+} \beta_{11} \text { Period }_{i t}+\varepsilon_{i t},
\end{aligned}
$$

where all variables are defined as mentioned above: $F R Q$ is the residual value of the McNichols (2002) model, Period is a dummy variable of 0 for the pre-IFRS adoption period and 1 for the post-IFRS adoption period.

\section{EMPIRICAL ANALYSIS}

\subsection{Descriptive analysis}

Table 1 summarizes descriptive statistics for the present study variables over three years from 2014 to 2018. Concerning board mechanisms, the results show that the range of board size (BSIZE) is between a minimum of 5 and 21 members setting in the board with a mean of 11 and standard deviation (SD) of 2.38. This indicates that the minimum number of board sizes is five members on the board, and the largest or maximum board size is 21 , with an average of 11 board members. Further, the portion of independent members (BIND) in the board ranges between a minimum of $13 \%$ and a maximum of $83 \%$ of the total number of board members with a mean of $51 \%$ and SD of $13 \%$. This demonstrates that at least $13 \%$ of the listed companies' board members are independent members with an average of $51 \%$. Concerning board diligence (BDEL), the results demonstrate that board diligence is at least $66 \%$, with a maximum of $100 \%$ and a mean of $87 \%$. This indicates that the attendance of board meetings by board members has a minimum of $66 \%$. Likewise, board financial expertise $(B E X P)$ is between a minimum of $50 \%$ and a maximum of $90 \%$ of board members who are financially literate in the field of accounting, management, and finance or related areas with a mean of $57 \%$ and SD of $15 \%$ (see Table 1 and Figure 2).

Table 1. Descriptive statistics of CG attributes

\begin{tabular}{l|c|c|c|c}
\hline Variables & Mean & Maximum & Minimum & Std. dev. \\
\hline FRQ & 0.15 & 3.18 & -1.15 & 0.75 \\
\hline BSIZE & 10.99 & 21 & 5 & 2.38 \\
\hline BIND & 0.51 & 0.83 & 0.13 & 0.13 \\
\hline BDEL & 0.87 & 1 & 0.66 & 0.07 \\
\hline BEXP & 0.57 & 90 & 0.50 & 0.15 \\
\hline ACSIZE & 3.91 & 7 & 3 & 0.91 \\
ACIND & 0.83 & 1 & 0.33 & 0.16 \\
\hline ACEXP & 0.76 & 1 & 0.33 & 0.18 \\
\hline ACDEL & 0.90 & 1 & 0.72 & 0.08 \\
\hline FOWN & 38.51 & 83 & 2.30 & 79.58 \\
BIG4 & 0.3125 & 1 & 0.00 & 0.46 \\
\hline
\end{tabular}

Note: BSIZE: board size; BIND: board independence; $B D E L$ : board diligence; BEXP: board expertise; ACSIZE: audit committee size; ACIND: audit committee independence; ACDEL: audit committee diligence; ACEXP: audit committee expertise; FOWN: foreign ownership; BIG4: audit quality.

Concerning AC attributes, the results illustrate that ACSIZE ranges between a minimum of 3 members and a maximum of 7 members in the committee with an average of 4 members. Further, AC independence $(A C I N D)$, which is one of the most important mechanisms of CG, has a minimum of $33 \%$ members as independent members in the $\mathrm{AC}$ and a maximum of $100 \%$ with an average of $83 \%$. This means that $\mathrm{AC}$ in listed companies have at least 

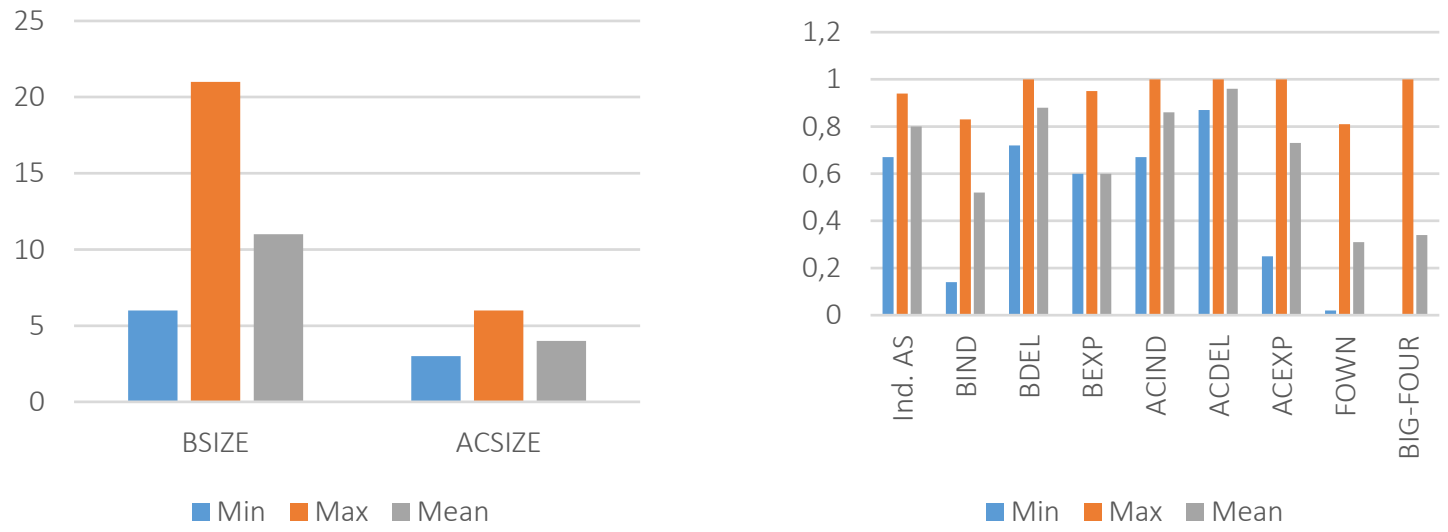

Figure 2. Descriptive statistics for CG attributes

two independent members out of three members setting in the AC with an average of 4 independent members out of 5 members of the total number of AC members. The results also indicate that the attendance of $\mathrm{AC}$ members (ACDEL) in the meeting of the committee conducted is scoring a minimum of $72 \%$ attendance and a maximum of $100 \%$ with an average of $90 \%$. AC expertise (ACEXP) is also between a minimum of $33 \%$ and a maximum of $100 \%$, with an average of $76 \%$ of the AC members who are financially literate. This suggests that the AC members' financial expertise in the listed companies from India in the field of accounting, finance, CG, and other related areas is at least onefourth of the total number of $\mathrm{AC}$ members or they are fully financially literate.

In terms of foreign ownership, the results indicate that the minimum percentage of foreign shares is $2.3 \%$, with an average of $39 \%$. Regarding audit quality measured by Big 4 international auditors, the results show that about $31 \%$ of the selected companies from India are audited by Big 4 against $69 \%$ audited by non-Big 4 .

\subsection{Correlation analysis}

The correlation results show a positive correlation of FRQ with BSIZE, BIND, BEXP, and ACEXP but a negative correlation with other variables. Besides, positive and negative relationships are observed between the independent variables. Further, the correlation coefficients indicate that FRQ has a positive association with all variables, except for BDEL, ACSIZE, FOWN, and BIG4. In contrast, in the case of Indian GAAP, the results show a negative correlation between FRQ and other variables except for BSIZE and BEXP. This indicates an improvement in the relationship between CG mechanisms and FRQ under Ind. AS, which is better than Indian GAAP. Overall, the correlation among the independent variables does not exceed 0.70 , which means that multicollinearity issues do not exist among the independent variables. The results of the correlation are available on request.

\subsection{Results and discussion}

Table 2 demonstrates the regression estimation of the results. The results show that the models are fit, indicated by a probability of $0.00(p<0.01)$ and a confidence interval of $99 \%$. Further, the adjusted $R^{2}$ is 0.21 , which means that variables used in the model contribute about $21 \%$ of the variability of the dependent variable (FRQ). It indicates that CG variables contribute about $21 \%$ to FRQ. Concerning the adjusted $R$-squared of accounting standards wise model in Table 3, it shows that the adjusted $R$-squared of the new accounting standards in India; Ind. AS (0.19) is less than the adjusted $R$-squared of the old accounting standards (local GAAP).

The impact of BSIZE on FRQ is statistically significant at the level of $1 \%$ ( $p$-value $=0.00<0.01$ ). This means that the size of the board has a statistically significant positive impact on the FRQ. Further, the impact of BSIZE on FRQ under the two sets of accounting standards demonstrates that BSIZE has a statistically significant impact on FRQ under both sets of accounting standards at the level of $1 \%$ ( $p$-value $=0.00<0.01)$. Thus, this leads to accept- 
Table 2. OLS regression analysis

\begin{tabular}{|c|c|c|c|c|}
\hline Variable & Coefficient & Std. error & t-statistic & Prob. \\
\hline C & 0.953 & 0.591 & 1.611 & 0.108 \\
\hline$B S I Z E$ & 0.093 & 0.016 & 5.953 & 0.000 \\
\hline BIND & 0.732 & 0.326 & 2.246 & 0.025 \\
\hline$B D E L$ & -1.320 & 0.545 & -2.421 & 0.016 \\
\hline$B E X P$ & 1.466 & 0.270 & 5.434 & 0.000 \\
\hline ACSIZE & -0.220 & 0.041 & -5.427 & 0.000 \\
\hline ACIND & -1.047 & 0.254 & -4.115 & 0.000 \\
\hline ACEXP & -0.456 & 0.240 & -1.900 & 0.058 \\
\hline$A C D E L$ & 0.277 & 0.509 & 0.544 & 0.587 \\
\hline FOWN & 0.000 & 0.000 & -0.351 & 0.726 \\
\hline$B I G 4$ & -0.194 & 0.078 & -2.480 & 0.014 \\
\hline$R$-squared & & - & - & 0.233 \\
\hline Adjusted $R$-squared & & - & - & 0.212 \\
\hline F-statistic & & - & - & 11.314 \\
\hline Prob. (F-statistic) & & - & - & 0.000 \\
\hline
\end{tabular}

ing $H_{0} 1$. This means that there no significant difference in the impact of board size on FRQ under both sets of accounting standards. Previous studies have also documented evidence of the impact of board size on FRQ. Onuorah et al. (2016) noted that a small board size would enhance its effectiveness and promote its communication among them and improve FRQ. However, Chalaki et al. (2012) and Ahmed and Duellman (2006) stated no connection between board size and FRQ.

Considering board independence (BIND), the results in Table 3 show that BIND has a statistically significant impact on FRQ at the level of 5\% $(p$-value $=0.03<0.02)$. This indicates that board independence contributes to FRQ. Concerning the impact of BIND under the different sets of accounting standards, the results show no statistical evidence to support the difference between both accounting standards (Ind. AS and Indian GAAP) ( $p$-value for both $>0.05)$. This means that eBIND effect on FRQ has not changed from Ind. AS to Indian GAAP. Thus, this leads to accepting the null hypothesis $H_{0} 2$. In contrast, Petra (2007) showed no relationship between CG attributes and FRQ.

Board diligence $(B D E L)$ indicates statistically significant effect at the level of $5 \%(p=0.02<0.05)$ on FRQ. This impact is negative, which indicates that board diligence contributes negatively to FRQ. However, one believes that the absolute number of meetings cannot evaluate $B D E L$; rather, board decisions and meetings minutes of books are a suit- able measure to evaluate the contribution of $B D E L$ to FRQ. Further, the impact of BDEL on FRQ has changed from a significant effect under Indian GAAP to an insignificant effect under Ind. AS. Therefore, $H_{0} 3$ is supported as the impact of $B D E L$ on FRQ has changed from local GAAP to Ind. AS. Sarkar et al. (2008) stated that more attentive boards consider the directors' participation, raising the level of earnings management and thus increasing the quality of knowledge.

The results in Table 3 show a statistically significant impact of BEXP on FRQ. It has a positive significant effect on FRQ at the level of $1 \%(p=0.00$ $<0.01$ ). However, the impact of BEXP on RFQ under the two sets of accounting standards remained unchanged. While it has a statistically significant effect at the level of $1 \%(p=0.00<0.1)$ in the case of Ind. AS, it has the same impact in the case of the Indian GAAP. Accordingly, $\mathrm{H}_{0} 4$ is supported. Consistently, García-Meca and Garcia-Sanchez (2018) confirmed that management skills play a crucial role in enhancing FRQ and that capable managers are less possibly to manipulate earnings on time to meet the bank's short-term earnings benchmarks.

AC size (ACSIZE) exhibits a significant but negative impact on FRQ at the level of $1 \%$. The significant impact of AC size on FRQ could be attributed to the range of AC size, ranging between a minimum of 3 and a maximum of 7 members in the committee with an average of 4 members. Concerning the impact of AC size on FRQ under 
Table 3. Accounting standards wise OLS regression analysis

\begin{tabular}{|c|c|c|c|c|c|c|c|c|}
\hline \multirow[b]{2}{*}{ Variable } & \multicolumn{4}{|c|}{ Ind. AS } & \multicolumn{4}{|c|}{ Indian GAAP } \\
\hline & Coefficient & Std. error & t-statistic & Prob. & Coefficient & $\begin{array}{l}\text { Std. } \\
\text { error }\end{array}$ & t-statistic & Prob. \\
\hline C & 0.636 & 1.001 & 0.636 & 0.526 & 2.494 & 0.855 & 2.915 & 0.004 \\
\hline BSIZE & 0.099 & 0.022 & 4.464 & 0.000 & 0.078 & 0.023 & 3.441 & 0.001 \\
\hline$B I N D$ & 0.988 & 0.499 & 1.979 & 0.049 & 0.833 & 0.451 & 1.847 & 0.066 \\
\hline$B D E L$ & -1.026 & 0.865 & -1.187 & 0.237 & -1.599 & 0.708 & -2.258 & 0.025 \\
\hline BEXP & 1.727 & 0.445 & 3.879 & 0.000 & 1.043 & 0.348 & 2.997 & 0.003 \\
\hline ACSIZE & -0.271 & 0.067 & -4.062 & 0.000 & -0.226 & 0.055 & -4.127 & 0.000 \\
\hline ACIND & -0.862 & 0.415 & -2.077 & 0.039 & -1.361 & 0.338 & -4.024 & 0.000 \\
\hline ACDEL & 0.280 & 0.760 & 0.369 & 0.713 & -0.384 & 0.748 & -0.514 & 0.608 \\
\hline ACEXP & -0.713 & 0.341 & -2.091 & 0.038 & -0.523 & 0.369 & -1.418 & 0.158 \\
\hline FOWN & 0.000 & 0.001 & 0.235 & 0.814 & -0.005 & 0.002 & -2.024 & 0.044 \\
\hline BIG4 & -0.186 & 0.118 & -1.581 & 0.116 & -0.177 & 0.107 & -1.657 & 0.099 \\
\hline$R$-squared & - & - & - & 0.232 & - & - & - & 0.288 \\
\hline $\begin{array}{l}\text { Adjusted } \\
R \text {-squared }\end{array}$ & - & - & - & 0.190 & - & - & - & 0.249 \\
\hline F-statistic & - & - & - & 5.420 & - & - & - & 7.397 \\
\hline $\begin{array}{l}\text { Prob. } \\
\text { (F-statistic) }\end{array}$ & - & - & - & 0.000 & - & - & - & 0.000 \\
\hline
\end{tabular}

the different sets of accounting standards, the results depict no change of this influence from the old accounting standards to the new accounting standards. It can also be concluded that the impact of ACSIZE on FRQ has not changed from Indian GAAP to Ind. AS. Thus, this leads to accepting $\mathrm{H}_{0}$ 5. Consistently, Pucheta-Martinez and De Fuentez (2007) found that the size of AC significantly influences the receipt of audit reports, including non-compliance or error qualifications.

AC structure indicated by the percentage of independent members of AC (ACIND) has a significant negative impact on FRQ at the level of $1 \%$ $(p=0.00<0.01)$. This means that AC independence is significantly but negatively linked with FRQ. As far as the different sets of accounting standards are considered, the significant impact of ACIND on FRQ has not changed. However, the effect of BIND under Indian GAAP ( $p=0.00$ $0.01<)$ is better than the new accounting standards; Ind. AS ( $p=0.040 .5<$ ). Accordingly, $H_{0} 6$ is accepted. The same results were also confirmed by Kamarudin et al. (2012) who reported that the independence of an $\mathrm{AC}$ was related to a higher quality of earnings. However, Choi et al. (2004) provided evidence of a negative association between AC members' independence and the management of earnings.
The results in Tables 2 and 3 illustrate the effect of ACDEL on FRQ is insignificant $(p=0.59<$ $0.10)$. This indicates that $B D E L$ has no impact on FRQ. However, the impact of ACDEL on FRQ under the different sets of accounting standards indicates no significant difference between the old accounting standards and the new accounting standards. The impact of ACDEL on FRQ under the new accounting standards (Ind. AS) $(p=0.71>0.10)$ has not changed from the old accounting standards (Indian GAAP) $(p=0.61$ $>0.10)$. Hence, this leads to accepting $H_{0} 7$. This matches with Davidson et al. (2005), and Choi, Jeon, and Park (2004) found that AC attributes were not significantly associated with earnings management.

The results in Table 2 also demonstrate statistically significant effect at the level of $10 \%$ on FRQ $(p=0.06<0.10)$. This signifies that listed companies may increase AC effectiveness by enhancing the financial expertise or increasing the financially literate members of AC members to be more prepared for Ind. AS convergence. Further, ACEXP shows statistically significant effect at the level of $5 \%(p=0.04<0.05)$ under the Ind. AS but there no significant effect in case of Indian GAAP. Thus, this leads to rejecting $\mathrm{H}_{0} 8$. Cohen et al. (2013) advocate that AC expertise positively influences FRQ. 
Foreign ownership statistically exhibits insignificant effect on FRQ at any level of significance $(1 \%, 5 \%$ and $10 \%)(p=0.73>0.10)$. This could be as a result that India has its accounting standards and has shifted to Ind. AS, which is equivalent to IFRS, rather than shifting to the global version of IFRS, may not attract foreign investors. Further, the effect of foreign ownership on FRQ has changed from a significant effect under the Indian GAAP to be insignificant under Ind. AS. This indicates that foreign ownership may think that the new accounting standards will not contribute to FRQ. Thus, this leads to rejecting $H_{0}$ 9. In contrast, Chalaki et al. (2012) found no connection between CG attributes like the concentration of ownership, institutional ownership, and FRQ. Further, some studies such as Y. Bozec and R. Bozec (2007) found that ownership concentration insignificantly affects FRQ.

The results in Table 2 show that Big 4 has a significant impact at the level of 5\% on FRQ ( $p=$ $0.01<0.5$ ). More importantly, when comparing the impact of Big 4 on FRQ shows that Big 4 is found to have an insignificant impact under both Indian GAAP and Ind. AS. Thus, this leads to accepting $H_{0} 10$. UAE is consistent with Onuorah et al. (2016) who revealed a positive effect of quality of external audit on FRQ measured by the discretionary accruals of the firm. Further, Davidson et al. (2005) stated that there is no association between the presence of a Big 5 auditor and earnings management.

\section{CONCLUSION}

The present research attempts to assess the influence of CG mechanisms on FRQ. CG mechanisms have been considered as independent variables, and FRQ is the dependent variable. CG mechanisms included in the model are board effectiveness (size, independence, diligence, and expertise), AC attributes (size, independence, diligence, and expertise), foreign ownership, and audit quality. Descriptive analysis was firstly provided for all independent, dependent, and control variables. Then, correlation analysis was conducted and discussed to diagnose the correlations among variables and explore multicollinearity problems. Finally, an estimation of the impact of CG mechanisms on FRQ was introduced by conducting OLS regression models. A sample of 97 firms listed on the Bombay Stock Exchange from 2014 to 2018 was used.

The results found that the size of the board has a statistically significant positive impact on the FRQ. Further, the impact of BSIZE on FRQ under the two sets of accounting standards demonstrated that BSIZE has a statistically significant impact on FRQ under both sets of accounting standards. Considering board independence (BIND), the results showed that BIND has a statistically significant impact on FRQ. Further, the impact of BIND under the different sets of accounting standards showed no statistical evidence to support the difference between both accounting standards (Ind. AS and Indian GAAP). Board diligence (BDEL) indicated a statistically significant negative effect on FRQ. However, the impact of $B D E L$ on FRQ has changed from a significant effect under Indian GAAP to an insignificant effect under Ind. AS. In the same context, BEXP exhibited a significant positive effect on FRQ, but this effect under the two sets of accounting standards remained unchanged. AC size (ACSIZE) exhibited a significant but negative impact on FRQ. This effect, under the different sets of accounting standards, was found to be the same. Further, AC independence was found to have a significant negative impact on FRQ and remained unchanged under the different sets of accounting standards. The results revealed that BDEL has no impact on FRQ and remained unchanged under different accounting standards. ACEXP showed a statistically significant effect on FRQ, and it has changed from insignificant under Indian GAAP to be significant under Ind. AS. Foreign ownership exhibited an insignificant effect on FRQ; however, the effect of foreign ownership on FRQ has changed from a significant effect under the Indian GAAP to be insignificant under Ind. AS. Finally, the results reported that Big-Four has a significant impact on FRQ; however, it was found to have an insignificant impact under both Indian GAAP and Ind. AS. 
Few empirical studies have investigated the impact of CG mechanisms on FRQ under the Indian GAAP and Ind. AS; however, to the best of the authors' knowledge, this study is the first attempt to investigate this issue using OLS models rather than pre- and post-analysis, which have not been considered by prior studies. Therefore, this study tries to bridge an existing gap in the body of literature on this issue. This study is limited to pre- and post-Ind. AS analysis. Future studies can increase the sample or the time frame to investigate the same issue. Besides, future research could increase and include some other variables of CG or compliance with Ind. AS.

\section{AUTHOR CONTRIBUTIONS}

Conceptualization: Faozi A. Almaqtari, Abdulwahid Abdullah Hashed, Mohd Shamim, Waleed M.

Alahdal.

Data curation: Faozi A. Almaqtari.

Formal analysis: Faozi A. Almaqtari, Abdulwahid Abdullah Hashed,.

Investigation: Faozi A. Almaqtari, Abdulwahid Abdullah Hashed, Mohd Shamim.

Methodology: Faozi A. Almaqtari, Abdulwahid Abdullah Hashed, Mohd Shamim, Waleed M. Alahdal.

Project administration: Faozi A. Almaqtari, Abdulwahid Abdullah Hashed.

Supervision: Faozi A. Almaqtari, Abdulwahid Abdullah Hashed.

Validation: Faozi A. Almaqtari, Abdulwahid Abdullah Hashed, Mohd Shamim, Waleed M. Alahdal.

Visualization: Abdulwahid Abdullah Hashed, Waleed M. Alahdal.

Writing - original draft: Faozi A. Almaqtari, Abdulwahid Abdullah Hashed, Waleed M. Alahdal.

Writing - review \& editing: Faozi A. Almaqtari, Abdulwahid Abdullah Hashed, Mohd Shamim, Waleed M. Alahdal.

\section{ACKNOWLEDGMENT}

This publication was supported by Deanship of Scientific Research, Prince Sattam Bin Abdulaziz University, Alkharj, Saudi Arabia.

\section{REFERENCES}

1. Abbott, L. J., Park, Y., \& Parker, S. (2000). The effects of audit committee activity and independence on corporate fraud. Managerial Finance, 26(11), 55-68. https://doi. org/10.1108/03074350010766990

2. Aggarwal, R., Erel, I., Ferreira, M., \& Matos, P. (2011). Does governance travel around the world? Journal of Financial Economics, 100(1), 154-181. https://doi.org/10.1016/j.jfineco.2010.10.018

3. Agrawal, A., \& Chadha, S. (2005). Corporate governance and accounting scandals. The Journal of Law and Economics, 48(2), 371-406. http://dx.doi. org/10.1086/430808

4. Ahmed, A. S., \& Duellman, S.
(2006). Evidence on the role of accounting conservatism in corporate governance. Journal of Accounting and Economics, 43(2-3), 411-437. https://doi.org/10.1016/j. jacceco.2007.01.005

5. Ahmed, K., Hossain, M., \& Adams, M. (2006). The effects of board composition and board size on the informativeness of annual accounting earnings. Corporate Governance: An International Review, 14(5), 418-431. https:// doi.org/10.1111/j.14678683.2006.00515.x

6. Aljaaidi, K. S. Y. (2013). Corporate governance and auditor choice among companies in GCC Countries (Doctoral dissertation). Universiti Utara Malaysia.

7. Al-Janadi, Y., Rahman, R. A.,
\& Alazzani, A. (2016). Does government ownership affect corporate governance and corporate disclosure? Evidence from Saudi Arabia. Managerial Auditing Journal, 31(8/9), 871-890. http://doi.org/10.1108/MAJ-122015-1287

8. Almaqtari, F. A., Al-Hattami, H. M., Al-Nuzaili, K. M., \& Al-Bukhrani, M. A. (2020). Corporate governance in India: A systematic review and synthesis for future research. Cogent Business \& Management, 7(1), 1803579. https://doi.org/10.1080/2 3311975.2020 .1803579

9. Almaqtari, F. A., Farhan, N. H., Al-Homaidi, E. A., \& Mishra, N. (2020). An empirical evaluation of financial reporting quality of the Indian GAAP and 
Indian accounting standards. International Journal of Accounting, Auditing and Performance Evaluation. (In Press). Retrieved from https://www.inderscience. com/info/ingeneral/forthcoming. php?jcode $=$ ijaape

10. Almaqtari, F. A., Shamim, M., Al-Hattami, H. M., \& Aqlan, S. A. (2020). Corporate governance in India and some selected Gulf countries. International Journal of Managerial and Financial Accounting, 12(2), 165-185. https://doi.org/10.1504/IJMFA.2020.109135

11. Al-Matari, E. M., Al-Swidi, A. K., \& Fadzil, F. H. (2014). The effect on the relationship between board of directors characteristics on firm performance in Oman: Empirical Study. Middle-East Journal of Scientific Research, 21(3), 556-574. Retrieved from https://www.researchgate.net/ publication/292368598_The_Effect_on_the_Relationship_between_Board_of_Directors_Characteristics_on_Firm_Performance_ in_Oman_Empirical_Study

12. Arouri, H., Hossain, M., \& Muttakin, B. (2014). Effects of board and ownership structure on corporate performance Evidence from GCC countries. Journal of Accounting in Emerging Economies, 4(1), 117-130. http://doi. org/10.1108/JAEE-02-2012-0007

13. Bagaeva, A. (2008). An examination of the effect of international investors on accounting information quality in Russia. Advances in Accounting, 24(2), 157-161. https://doi. org/10.1016/j.adiac.2008.08.001

14. Beasley, M. (1996). An empirical analysis of the rotation between the board of director composition and financial statement fraud. The Accounting Review, 71(4), 443-465. Retrieved from https://qut.rl.talis. com/items/8B68DCF0-18F058E0-7F74-ACF628D049B6.html

15. Beasley, M. S., Carcello, J. V., Hermanson, D. R., \& Neal, T. L. (2009). The Audit committee oversight process. Contemporary Accounting Research, 26(1), 65-122. https://doi.org/10.1506/car.26.1.3

16. Becker, C., DeFond, M.,
Jiambalvo, J., \& Subramanyam, K. (1998). The effect of audit quality on earnings management. Contemporary Accounting Research, 15(1), 1-24. https://doi. org/10.1111/j.1911-3846.1998. tb00547.x

17. Bedard, J., Chtourou, S. M., \& Courtteau, L. (2004). The effect of audit committee expertise, independence, and activity on aggressive earnings management. Auditing: A Journal of Practice and Theory, 23(2), 13-35. https://doi. org/10.2308/aud.2004.23.2.13

18. Bozec, Y., \& Bozec, R. (2007). Ownership concentration and corporate governance practices: substitution or expropriation effects? Canadian Journal of Administrative Sciences, 24(3), 182-195. https://doi.org/10.1002/ cjas. 23

19. Brown, J., Falaschetti, D., \& Orlando, M. (2010). Auditor independence and earnings quality: Evidence for market discipline vs. Sarbanes-Oxley proscriptions. American Law and Economics Review, 12(1), 39-68. http://dx.doi.org/10.2139/ ssrn.940847

20. Carcello, J. V., \& Neal, T. L. (2003). Audit committee characteristics and auditor dismissals following "new" going- concern reports. The Accounting Review, 78(1), 95-117. https://doi.org/10.2308/ accr.2003.78.1.95

21. Chalaki, P., Didar, H., \& Riahinezhad, M. (2012) Corporate governance attributes and financial reporting quality: Empirical evidence from Iran. International Journal of Business and Social Science, 3(15), 223-229. Retrieved from http://ijbssnet. com/journals/Vol_3_No_15_August_2012/25.pdf

22. Chen, G., Firth, M., Gao, D., \& Rui, O. (2006). Ownership structure, corporate governance, and fraud: Evidence from China. Journal of Corporate Finance, 12(3), 424-448. https://doi. org/10.1016/j.jcorpfin.2005.09.002

23. Cho, S., \& Rui, O. M. (2009). Exploring the effects of China's two-tier board system and ownership structure on firm performance and earnings informativeness. Asia-Pacific Journal of Accounting \& Economics, 16(1), 95-117. https://doi.org/10.10 80/16081625.2009.9720831

24. Choi, J. H., Jeon, K. A., \& Park, J. I. (2004). The role of audit committees in decreasing earnings management: Korean evidence. International Journal of Accounting, Auditing and Performance

Evaluation, 1(1), 37-60. https://doi. org/10.1504/IJAAPE.2004.004142

25. Chou, H. I., Li, H., \& Yin, X. (2010). The effects of financial distress and capital structure on the work effort of outside directors. Journal of Empirical Finance, 17(3), 300-312. https:// doi.org/10.1016/j.jempfin.2009.12.005

26. Cohen, J., Hoitash, U., Krishnamoorthy, G., \& Wright, A. (2013). The effect of audit committee industry expertise on monitoring the financial reporting process. The Accounting Review, 89(1), 243-273. https://doi. org/10.2308/accr-50585

27. Davidson, R., Goodwin-Stewart, J., \& Kent, P. (2005). Internal governance structures and earnings management. Accounting \& Finance, 45(2), 241-267. https://doi.org/10.1111/j.1467629x.2004.00132.x

28. DeFond, M., Hann, R., \& Hu, X. (2005). Does the market value financial expertise on audit committees of boards of directors? Journal of Accounting Research, 43(2), 153-193. https://doi.org/10.1111/j.1475679x.2005.00166.x

29. Deloitte. (2017). Roadmap drawn up for IFRS convergence of Indian banks and insurers. Retrieved from https://www.iasplus.com/en/ news/2016/01/india-banks

30. Ditropoulos, P., \& Asteriou, D. (2010). The effect of board composition on the informativeness and quality of annual earnings: Empirical evidence from Greece. Research in International Business and Finance, 24(2), 190-205. https://doi. org/10.1016/j.ribaf.2009.12.001 
31. Dong, M., \& Xue, Q. (2010). The effect of governance transparency on earnings response coefficient: Evidence from emerging markets. International Journal of Accounting, Auditing and Performance Evaluation, 6(2/3), 158-190. https://doi.org/10.1504/ IJAAPE.2010.031608

32. Felo, A. J., Krishnamurthy, S., \& Solieri, S. A. (2003). Audit committee characteristics and the perceived quality of financial reporting: an empirical analysis (Working Paper). Pennsylvania State University.

33. Firth, M., Fung, P. M., \& Rui, O. M. (2007). How ownership and corporate governance influence chief executive pay in China's listed firms. Journal of Business Research, 60(7), 776-785. https://doi. org/10.1016/j.jbusres.2007.01.014

34. García-Meca, E., \& Garcia-Sanchez, I.-M. (2018). Does managerial ability influence the quality of financial reporting? European Management Journal, 36(4), 544-557. http://doi.org/10.1016/j. emj.2017.07.010

35. Habbash, M., \& Alghamdi, S. (2015). The perception of earnings management motivations in Saudi public firms. Journal of Accounting in Emerging Economies, 5(1), 122147. http://doi.org/10.1108/JAEE06-2012-0025

36. Hundal, S. (2013). Independence, expertise and experience of audit committees: Some aspects of Indian corporate sector. American International Journal of Social Science, 2(5), 58-75. Retrieved from http://www.aijssnet.com/journal/ index/88

37. Kamarudin, K. A., Ismail, W. A. W., \& Samsuddin, M. E. (2012) The influence of CEO duality on the relationship between audit committee independence and earnings quality. Procedia-Social and Behavioral Sciences, 65, 919924. https://doi.org/10.1016/j. sbspro.2012.11.220

38. Koh, P. S., Laplante, S. K., \& Tong, Y. H. (2007). Accountability and value enhancement roles of corporate governance. Accounting and Finance, 47(2), 305-333. https://doi.org/10.1111/j.1467629X.2006.00207.x

39. KPMG. (2015). IFRS convergence: A reality now. Retrieved from https://www.kpmg.com/IN/en/ IssuesAndInsights/ArticlesPublications/IFRS-Notes/Documents/ KPMG-IFRS-Notes-IndAS.pdf.

40. Krishnan, G., \& Visvanathan, G. (2008). Does the SOX definition of an accounting expert matter? The association between audit committee directors accounting expertise and accounting conservatism. Contemporary Accounting Research, 25(3), 827858. http://dx.doi.org/10.1506/ car.25.3.7

41. Lee, E., Walker, M., \& Zeng, C. (2013). Does IFRS Convergence Affect Financial Reporting Quality in China? (ACCA Research Report). Association of Chartered Certified Accountants \& Certified Accountants Educational Trust, London. Retrieved from https:// research-information.bris.ac.uk/ en/publications/does-ifrs-convergence-affect-financial-reportingquality-in-china

42. McNichols, M. (2002). Discussion of the quality of accruals and earnings: The role of accrual estimation errors. The Accounting Review, 77(s-1), 61-69. https://doi. org/10.2308/accr.2002.77.s-1.61

43. Nassar, M., \& Jrisat, A. (2020) The application of corporate governance rules in the UAE. International Journal of Economics and Business Research, 19(3), 223244. http://dx.doi.org/10.1504/ IJEBR.2020.106522

44. Onuorah, Chi-Chi, A., \& Friday, I. O. (2016). Corporate governance and financial reporting quality in selected Nigerian company. International Journal of Management Science and Business Administration, 2(3), 7-16. Retrieved from https://researchleap. com/wp-content/uploads/2016/03/ Corporate-Governance-andFinancial-Reporting-Quality-inSelected-Nigerian-Company.pdf

45. Petra, S. T. (2007). The effects of corporate governance on the informativeness of earnings. Economics of Governance, 8,
129-152. https://doi.org/10.1007/ s10101-006-0018-8

46. Pucheta-Martinez, M. C., \& De Fuentez, C. (2007). The impact of audit committee characteristics on the enhancement of the quality of financial reporting: An empirical study in the Spanish context. Corporate Governance, 15(6), 1394-1412. https://doi.org/10.1111/ j.1467-8683.2007.00653.x

47. Rahman, R. A., \& Ali, F. H. M. (2006). Board, audit committee, culture and earnings management: Malaysian evidence. Managerial Auditing Journal, 21(7), 783-804. https://doi. org/10.1108/02686900610680549

48. Sarkar, J., Sarkar, S., \& Sen, K. (2008). Board of directors and opportunistic earnings management: evidence from India. Journal of Auditing and Finance, 23(4), 269-286. https://doi.org /10.1177/0148558X0802300405

49. Teoh, S., \& Wong, T. (1993). Perceived auditor quality and the earnings response coefficients. The Accounting Review, 68(2), 346-367. Retrieved from https://www.jstor. org/stable/248405

50. Van der Zahn, J.-L. W. M., \& Tower, G. (2004). Audit committee features and earnings management: further evidence from Singapore. International Journal of Business Governance and Ethics, 1(2/3), 233-258. https://doi.org/10.1504/ IJBGE.2004.005257

51. Watts, R. L., \& Zimmerman, J. L. (1983). Agency problems, auditing, and the theory of the firm: Some evidence. Journal of Law and Economics, 26(3), 613-633. https:// doi.org/10.1086/467051?journalC ode $=$ jle

52. Xie, B., Davidson, W., \& DaDalt, P. (2003). Earnings management and corporate governance: The roles of the board and the audit committee. Journal of Corporate Finance, 9(3), 295-317. https://doi.org/10.1016/ S0929-1199(02)00006-8

53. Yang, J. S., \& Krishnan, J. (2005). Audit committees and quarterly earnings management. International Journal of Auditing, 9(3), 1-21. https://doi.org/10.1111/ j.1099-1123.2005.00278.x 


\section{APPENDIX A}

Table A1. Operational definition of variables

\begin{tabular}{|c|c|c|c|}
\hline Variables & Measures & Evidence & Description \\
\hline \multicolumn{4}{|c|}{ Independent variables: board of directors' effectiveness } \\
\hline Size & BSZE & Arouri et al. (2014) & Total No. of the members of BOD \\
\hline Independence & BIND & Al-Janadi et al. (2016) & $\begin{array}{l}\text { No. of Independent board members / total No. } \\
\text { of BOD }\end{array}$ \\
\hline Diligence & BDEL & Al-matari et al. (2014) & $\begin{array}{l}\text { Total No. of meetings attended by all board } \\
\text { members/ total No. of meetings held during the } \\
\text { year }\end{array}$ \\
\hline Expertise & BEXP & $\begin{array}{l}\text { Xie et al. (2003), Agrawal and Chadha (2005), } \\
\text { AlJaaidi (2013) }\end{array}$ & $\begin{array}{l}\text { No. of board with financial and managerial } \\
\text { expertise to the total No. of board members }\end{array}$ \\
\hline Size & ACSIZE & $\begin{array}{l}\text { Yang and Krishnan (2005), Habbash and Alghamdi } \\
\text { (2015) }\end{array}$ & Total No. of the members of AC \\
\hline Independence & ACIND & Al-Janadi et al. (2016) & $\begin{array}{l}\text { No. of independent } A C \text { members / total No. of } \\
\qquad A C \text { members }\end{array}$ \\
\hline Diligence & ACDEL & AlJaaidi (2013) & $\begin{array}{c}\text { Total No. of meetings attended by all AC } \\
\text { members / total No. of meetings held during } \\
\text { the year }\end{array}$ \\
\hline Expertise & ACEXP & Habbash and Alghamdi (2015), AlJaaidi (2013) & $\begin{array}{c}\text { No. of AC members with financial and } \\
\text { managerial expertise to the total No. of board } \\
\text { members }\end{array}$ \\
\hline $\begin{array}{l}\text { Foreign } \\
\text { ownership }\end{array}$ & FOWN & Arouri et al. (2014) & $\%$ of shares held by foreigners \\
\hline Audit quality & Big4 & $\begin{array}{l}\text { Al-Janadi et al. (2016), Habbash and Alghamdi } \\
\text { (2015) }\end{array}$ & 1 if a firm audited by Big 4 or 0 otherwise \\
\hline
\end{tabular}

